\title{
Library and Information Service
}

\section{Recent donations}

We wish to thank the following author-members, and others, who have generously donated copies of their works to the College Library.

Suman Fernando, David Ndegwa \& Melba Wilson (1998) Forensic Psychiatry, Race and Culture. London: Routledge.

Cosmo Hallström \& Nicola McClure (1998) Anxiety and Depression-Your Questions Answered. Edinburgh: Churchill Livingstone.

David Healy (1997) The Anti-Depressant Era. Cambridge, MA \& London: Harvard University Press.

Doris Hollander (1998) Developing Mental Health Services. A Manual. London: Concern Publications.

Heinz Katschnig, Hugh Freeman ${ }^{1}$ \& Norman Sartorius (1997) Quality of Life in Mental Disorder. Chichester: Wiley.

Michael I. Levi (1998) Basic Notes in Psychiatry (2nd edn). Reading: Petroc Press, an imprint of LibraPharm Ltd.

Jean O'Hara \& Anthea Sperlinger (eds) (1997) Adults with Learning Disabilities. A Practical
Approach for Health Professionals. Chichester: John Wiley.

Brian O'Shea (1998) Schizophrenia, The Cutting Edge, Volume 2: Management Issues. Dublin: Eastern Health Board.

Basant K. Puri \& Peter J. Tyrer ${ }^{1}$ (1998) Sciences Basic to Psychiatry (2nd edn). Edinburgh: Churchill Livingstone.

Mary M. Robertson \& Simon Baron-Cohen (1998) Tourette Syndrome - The Facts. Oxford: Oxford University Press.

Anthony Stevens \& John Price (1996) Evolutionary Psychiatry, A New Beginning. London: Routledge.

Peter Tyrer \& Derek Steinberg (1998) Models for Mental Disorder: Conceptual Models in Psychiatry (3rd edn). Chichester: Wiley.

David Whealey \& David Smith (eds) (1998) Psychopharmacology of Cognitive and Psychiatric Disorders in the Elderly. London: Chapman and Hall Medical.

Greg Wilkinson (1997) Understanding Stress. London: Family Doctor Publications in Association with the BMA.

1. Indicates donor, where not first author.

This list is an acknowledgement of donors, not a current awareness or last acquisitions list. If members are interested in the publications listed, they are invited to contact the Library, which can supply full bibliographic detalls from the database, and a monthly current awareness list of latest acquisitions. 